\title{
ON THE WORK OF ALEXANDER OF TRALLES
}

\author{
O RADU ALEKSANDRA IZ TRALLESA
}

Kripouri Panagiota", Filippou Dimitrios*

\begin{abstract}
SUMMARY
Helminthiasis is known to man since antiquity, but it still remains a significant public health problem. In ancient times many plants have been tried as possible therapeutics in search of an effective drug. This manuscript investigates ancient beliefs on parasitic worm infestation. Moreover, Alexander of Tralles' $(525-605$ CE) suggestions on the treatment of this condition are discussed as found in his lesser-known work "A letter on helminth", along with comments on the use of those herbal cures by modern medicine.
\end{abstract}

Keywords: Helminthiasis; worm infestation; parasites; history; Alexander from Tralles; Byzantium

\section{INTRODUCTION}

From antiquity to recent times, worm infestation remains a significant public health issue. Helminths are mentioned in the ancient Greek literature and Ebers papyri of the ancient Egyptians. Ayurvedic physicians have also cited cases of infestation. By the Roman period, hygiene standards had improved; however, this problem had not subsided. According to the WHO

Department of Anatomy and Surgical Anatomy, Medical School, National and Kapodistrian University of Athens, Athens, Greece.

Correspondence Address: Panagiota Kripouri, Gymnasiarchou Stefanou 24, GR-54250, Harilaou, Thessaloniki, Greece; E-mail: p_kripouri@yahoo.com. 
statistics, it has been estimated that today, approximately $\mathrm{I} .5$ billion people are infected with soil-transmitted worms. ${ }^{1}$

In the past, numerous efforts have been made to find a specific treatment. Ancient Greeks, Egyptian, and Indian doctors tried a wide variety of plants and surgical approaches and experimented to find a cure. However, the result was poor until the discovery of anthelmintic drugs. It seems that ancient Egyptian doctors were well aware of at least the taeniasis, and their therapeutic approach was the use of pumpkin seeds. ${ }^{2}$ There has been a significant dispute among researchers about whether " $\alpha \alpha \alpha$ " appearing in ancient medical papyri could stand for haematuria due to schistosomiasis or not. ${ }^{3}$ In Ebers papyri, it has been suggested that guinea worm (Dracunculus medinensis) should be extracted with great care from a foot so as not to leave part of the worm in the limb. ${ }^{4}$

In ancient Greece, Hippocrates of Kos (known as "the father of medicine") classified worms in three groups (probably equivalent to roundworms, tapeworms, and pinworms). He also described cases of helminthiasis and the therapeutic approaches mainly using seseli (according to Trompoukis et al. parsley) and garlic because anthelmintic drugs were not evolved at that time. ${ }^{5,6} \mathrm{He}$ maintained that worms were present in one's body while still in the womb and believed that they did not cause serious illness and could remain in the host until his death.?

Galen also classified three different types of worms and proposed treating them with mint, cardamom, and myrrh. ${ }^{8}$ Alexander of Tralles also mentioned these treatments centuries after Galen. Surprisingly, all three

1 WHO (updated September 2017), Soil transmitted helminth infections - Fact sheet,http:// www.who.int/mediacentre/factsheets/fs366/en/, last retrieved 23/01/2018, 3:38 am.

2 Del Brutto OH, García HH. (2015) Taenia solium Cysticercosis -The lessons of history. J Neurol Sci. 359(1-2):392-5.

3 Othman AA, Soliman RH. (2015) Schistosomiasis in Egypt: A never-ending story? Acta Trop. 148:179-90.

4 Adamson PB. (1988) Dracontiasis in antiquity. Med Hist. 32(2):204-209.

5 Trompoukis C, German V, Falagas ME. (2007) From the roots of parasitology: Hippocrates' first scientific observations in helminthology. J Parasitol. 93(4):970-2.

6 Petrovska BB. (2012) Historical review of medicinal plants' usage. Pharmacogn Rev. 6(11):1-5.

7 Rendle-Short J. (2011) Worms in History with Special Reference to Children. Proc R Soc Med. 1957;50(12):1013-1018; Dolianiti M. Hippocrates as a pediatrician (Doctoral Dissertation). National and Kapodistian University of Athensp. 43.

8 Jirsa F, Winiwarter V. (2010) Intestinal helminths in the works of Galen. Wien Klin Wochenschr. 122Suppl3:14-8. 
remedies have been still researched today for possible anthelmintic proprieties. ${ }^{9,10,11}$ Even though the Romans had developed better hygiene standards with flushing latrines and running water, helminthiasis must have been a major public health issue in the Roman Period when Galen lived and practiced. ${ }^{12}$ Since the ancient Greeks had noticed the connection between pork and the parasites, it is supported that this belief was the original inspiration behind the prohibition of pork consumption in the Quran. ${ }^{13}$

\section{The case of Harod Agrippa}

'The most famous case of intestinal obstruction associated with worm infestation' is the story of Agrippa I, the king of Judea from 4I-44AD.14 The king was allegedly eaten by worms after he had committed hubris towards God during an oration. Compiled descriptions from St. Luke and Josephus led to the conclusion that helminthiasis could have been the cause of Agrippa's malady, ${ }^{15}$ which was a hypothesis discussed in other studies as well. ${ }^{16,17}$

Parasitic worms were also mentioned in traditional Indian medicine. In Atharvaveda, the last Veda of Hindu literature, worms are recognized as a cause of disease. ${ }^{18}$ Threadworms and roundworms are mentioned, and helminthiasis cases are described. In Sushruta Samhita, there is a description of what is known today as elephantiasis of the foot, although the case was

9 Dejani NN, Souza LC, Oliveira SR, Neris DM, Rodolpho JM, Correia RO2, Rodrigues V, Sacramento LV, Faccioli LH, Afonso A, Anibal FF. (2014) Immunological and parasitological parameters in Schistosoma mansoni-infected mice treated with crude extract from the leaves of Mentha x piperita L. Immunobiology. 219(8):627-32.

10 de Castro CC, Costa PS, Laktin GT, de Carvalho PH, Geraldo RB, de Moraes J, Pinto PL, Couri MR, Pinto Pde F, Da Silva Filho AA. (2015) Cardamonin, a schistosomicidal chalcone from Piper aduncum L. (Piperaceae) that inhibits Schistosoma mansoni ATP diphosphohydrolase. Phytomedicine. 22(10):921-8.

11 El-Sayad M, Abu Helw S, El-Taweel H, Aziz M. (2017) Antiparasitic Activity of Mirazid, Myrrh Total Oil and Nitazoxanide Compared to Praziquantel on Schistosoma mansoni: Scanning Electron Microscopic Study. Iran J Parasitol. 12(3):446-452.

12 Mitchell PD. (2017) Human parasites in the Roman World: health consequences of conquering an empire. Parasitology. 144(1):48-58.

13 Del Brutto OH, García HH. (2015), 392-5.

14 Rendle-Short J. (2011), 43.

15 Ibid.

16 Leatherwood C, Panush RS. (2017) Did King Herod suffer from a rheumatic disease? Clin Rheumatol. 36(4):741-744.

17 Ashrafian H. (2005) Herod the Great and his worms. J Infect. 51(1):82-3.

18 Prasad PV. (2002) General medicine in Atharvaveda with special reference to Yaksma (consumption/tuberculosis). Bull Indian Inst Hist Med Hyderabad. 32(1):1-14. 
attributed to humoral accumulation. ${ }^{19,20}$ In Ayurvedic medicine, elephantiasis was referred to as "shlipada". Shli means elephant.

Many significant physician figures of the past have proposed their views on a possible treatment. Our research focuses on a lesser-known work of Alexander of Tralles (Alexander Trallianus), a Byzantine doctor who devoted part of his work to the study of helminths. We tried to investigate whether the remedies mentioned in his work are still used as anthelmintics, regardless of the type of helminth against which they are used.

\section{Alexander from Tralles $\left(6^{\text {th }}\right.$ Century CE)}

\section{His PRofile}

Alexander of Tralles was the last spur of a well-known family of the Byzantine era; his older brothers were Anthemius, the architect of Hagia Sophia - the Orthodox patriarchal Basilica church; Metrodorus, a grammarian; Dioscurus, a physician, and Olympius, a jurist. Their father, Stephen, was a physician himself. Alexander is believed to have travelled a lot collecting medical knowledge from various places around the Mediterranean Sea. ${ }^{21}$ He practiced medicine in Rome. Although he practiced Galenic medicine and explained the illness according to the Hippocratic motif, he did struggle to evolve therapeutic approaches of his time, questioning the effectiveness of older treatments when he had to. ${ }^{22}$ The known part of his work consists of a twelve-volume book entitled "Therapeutics" and a letter to his friend

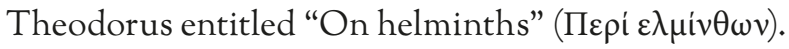

We studied Julius Ludwig Ideler's "Physici et medici Graeci Minores", as printed by Typis et impensis G. Reimeri in 1841. We focus our research on Alexander of Tralles' work "(Letter) On helminths" ["(E $\left.\varepsilon \lambda \mu i v \theta \omega v_{»}\right]$. This work is a letter to his friend Theodorus who wrote to Alexander asking for help because his child was suffering from a worm infestation.

19 Golzari SE, Kazemi A, Ghaffari A, Ghabili K. (2012) A brief history of elephantiasis. Clin Infect Dis. 55(7):1024.

20 Warrier PK. (1995) Filariasis (Shlipada). Bull Indian Inst Hist Med Hyderabad. 25(1-2):38-45.

21 Panteleakos G. (2013) Physiology in the Byzantine Period 330-1453 AD (Doctoral Dissertation). National and Kapodistrian University of Athens. p. 58.

22 Bouras-Vallianatos P. (2014) Clinical experience in late antiquity: Alexander of Tralles and the therapy of epilepsy. Med Hist. 58(3):337-53. 


\section{His WORK}

\section{On The TAXONOMY}

Alexander of Tralles uses the Hippocratic classification ${ }^{6}$ of the worms dividing them into "Ascaris", roundworms and flatworms. He states that thin and small worms are generated in the last part of the large intestine, while roundworms are found in the upper part of the intestine, so they can reach the stomach and they can be vomited out. Flatworms are so long that, as he asserts, they can expand to the intestines. Alexander of Tralles seems to believe that worms are generated by sepsis. He advises the reader that if one specifies the kind of the worm and their location in the gastrointestinal tract, he will be able to treat them.

\section{ON THE SYMPTOMS}

Alexander of Tralles describes that a person infected with worms is sleepless, restless, and suffers colic pain. As the malady proceeds, the pulse is weakened, thready, and irregular. The patient has a foul breath smell, an altered mental state, he grinds his teeth and rubs his lips together. He loses

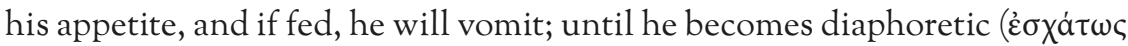

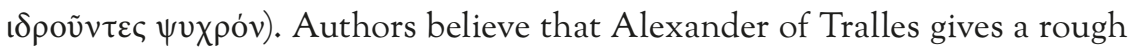
description of shock.

\section{ON TREATMENT}

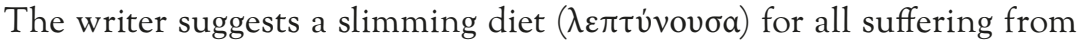
parasites. Reduction diets were known from antiquity and were used by the doctors of that time. ${ }^{23} \mathrm{He}$ also suggests beverages based on chamomile and celery roots. The use of water-oil/honey (mead) mixture or chamomile is considered to have a laxative effect. A wine-oil mixture together with the herb absinthium (a $\psi$ iv $\theta$ เov) was used as a poultice.

\section{FOR PATIENTS WITH FEVER}

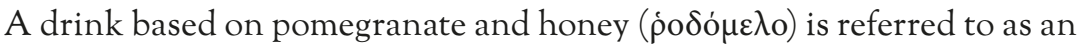
anthelmintic drug in the text because of its bitterish taste and is supposed to be given to patients with a high fever. It does not make the patient thirsty

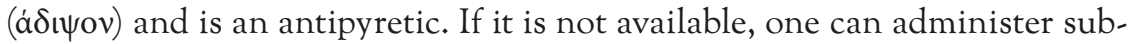

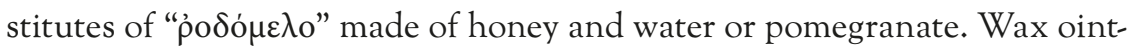
ment with rose extract should be applied to the skin. This mixture should be heated for a while, and then copper should be added in a mortar bowl

23 Christopoulou-Aletra H, Papavramidou N. (2004) Methods used by the hippocratic physicians for weight reduction. World J Surg. 28(5):513-7. 
with some water and rose extract, crushed by a pestle until it forms an ointment. This is an antipyretic, according to Alexander of Tralles, but it is also an anthelmintic and an appetite booster. This mixture can also be used in erysipelas, anthrax, and infections of the digits, rheumatic diseases, and chronic headaches. The mixture is made by common bugloss, and then can also be used for fever. If the oil/water mixture is added to the latter, it can

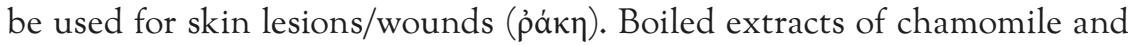
mellilota - which gave promising results for veterinarian medicine in modern-day research, ${ }^{24}$ and absinthium with water can also be used for treating skin problems. He seems to believe that bitter mixtures do not cure problems of the lower gastrointestinal tract, contrary to honey, and that they cause the helminths migrate to the upper gastrointestinal system. If all of the above is done and there is still fever and thirst, then he suggests "the cold, wet diet" based on ptisan barley with vinegar and celery roots. Interestingly, ptisan barley was the base for both diet and medicine. It was also used in therapeutic enemas. ${ }^{25}$

The patient should eat vegetables and herbs, especially chicory and lettuce with vinegar. If he remains thirsty, he should eat the inner part of melon and mulberries, which are considered to have laxative properties, and modern medicine seems to agree. ${ }^{26}$ Alexander of Tralles also suggests fish with vinegar and pigeons for those who suffer from helminthiasis with fever.

\section{For PATIENTS WITH NO FEVER}

Those who do not have a fever should not eat melon or drink mead, and a slimming diet is recommended. Celery, leek, Tordylium apulum and

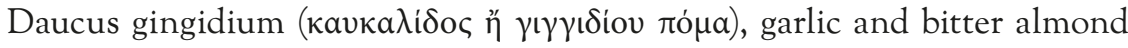
are all considered beneficial. Nigella with cumin, vinegar and mastic or caper and an (Artemisia) abrotanum based beverage, absinthium, mint, dittamy, kyphi, thiriac, jet stone, bull bile, dear brain, and wax ointment are all considered therapeutic as well. Nigella has been recently researched as a

24 Acharya J, Hildreth MB, Reese RN. (2014) In vitro screening of forty medicinal plant extracts from the United States Northern Great Plains for anthelmintic activity against Haemonchus contortus. Vet Parasitol. 201(1-2):75-81.

25 Vassilyadi F, Panteliadou AK, Panteliadis C. (2013) Hallmarks in the history of enteral and parenteral nutrition: from antiquity to the 20th century. Nutr Clin Pract. 28(2):209-17.

26 Akhlaq A, Mehmood MH, Rehman A, Ashraf Z, Syed S, Bawany SA, Gilani AH, Ilyas M, Siddiqui BS. (2016) The Prokinetic, Laxative, and Antidiarrheal Effects of Morus nigra: Possible Muscarinic, $\mathrm{Ca}(2+)$ Channel Blocking, and Antimuscarinic Mechanisms. Phytother Res. 30(8):1362-76. 
therapeutic. ${ }^{27}$ Kyphi was an unguent used in rituals. ${ }^{28}$ The theriac had analgesic properties. ${ }^{29}$

\section{TREATMENT FOR FLAT WORMS}

Alexander of Tralles suggests a variety of possible anthelmintics; cardamom, cistus, "kikinon oil" - he is probably referring to Ricinus communis seeds extract, castor oil ${ }^{30}$, nuts, peach tree bark extract, myrtle, poppy, tansy, mulberry root bark boiled with water, sunflower, nitre, and hyssop. As for

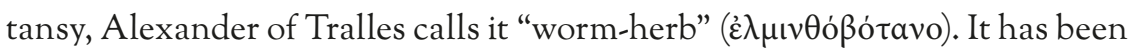
connected with Tanacetum vulgare. ${ }^{31}$ Recent research shows it is possibly an anthelmintic. ${ }^{32}$ One should drink cardamomin with water and garum spice or honey. The root of the plant "white chameleon" together with wine and oregano is according to Alexander of Tralles an antihelmintic. Hyssop and the root of cardamomin with honey and scammony and black hellebore are mixed in another remedy. Centaurium is also used with cumin. Nigella and the root of squash with honey and lithospermum with flour are used as a poultice with specific instructions provided by Alexander of Tralles.

\section{TREATMENT FOR ROUND WORMS}

For roundworms, cabbage seeds cooked with oil and peganum are suggested. Adrachne and absinthium alone or with rice and honey, boiled jet stone and hysopp cooked with liver and water, mint with vinegar, calamintha, thymes, and rikoo are all considered anthelmintic.

\section{TREATMENT FOR ASCARIS}

The cedar tree, wine, and flour are all mentioned as remedies. Boiled barley (or barley wine) is mixed with chamomile and used as an enema. Ivory

27 Ali M, Eldahab MA, Mansour HA, Nigm A. (2016) Schistosoma mansoni: Antiparasitic effects of orally administered Nigella sativa oil and/or Chroococcus turgidus extract. Acta Biol Hung. 67(3):247-60.

28 Martelli M. (2018) Translating Ancient Alchemy: Fragments of Graeco-Egyptian Alchemy in Arabic Compendia. Ambix. pp. 1-17.

29 Ramoutsaki IA, Dimitriou H, Kalmanti M. (2002) Management of childhood diseases in the Byzantine period: I -- analgesia. Pediatr Int. 44(3):335-7.

30 Lev E., Amar Z. (2008) Practical Materia Medica of the Medieval Eastern Mediterranean According to the Cairo Genizah. Brill. p. 375.

31 Koraēs A. (1832) Atakta, ègun pantodapōn eis tēn archaian kai tēn nean hellēniken glōssan autoschediōn sēmeiōseōn, kai tinōn allōn hypomnematōn autoschedios synagōgè: Alphabēton deuteron. Didot. Vol 4. p. 286.

32 Godinho LS, Aleixo de Carvalho LS, Barbosa de Castro CC, Dias MM, Pinto Pde F, Crotti AE, Pinto PL, de Moraes J, Da Silva Filho AA. (2014) Anthelmintic activity of crude extract and essential oil of Tanacetum vulgare (Asteraceae) against adult worms of Schistosoma mansoni. Sci World J. 2014:460342. 
filings, cyclamen, aloe, rose oil, chicory with vinegar, garlic, and abrotanum are all described as anthelmintic. Chicory has been under research. ${ }^{33}$

\section{Discussion And Conclusion}

Helminthiasis has been known since the antiquity and is well described. The uses of absinthium, mulberries, abrotanum, poppy, black hellebore, centaurium, hyssop, peganum, adrachne, and korio were considered therapeutic in ancient times, and over the centuries it has not been changed. All herbs are mentioned in Dioscurides' "Da Materia Medica" in It century AD. ${ }^{34}$ Even if ancient medicine is full of theological references and irrational concepts, ancient physicians will write down what was to their best knowledge a cure, ensuring that it will be passed on to their future colleagues. Their work provides us not only with their beliefs on malady and treatment, but also with a thesaurus on the nomenclature of herbs through time. The authors would like to mention that scientific names for herbs and plants as well as common names were used in this paper. This was unavoidable since no author contributing to this text has had training in the field of botanology. Additionally, we by no means aspire to present an exact translation of Tralles' work and our paper is rather a rendering of the content of his lesser-known text. Hopefully, the hereby presented Tralles' work "On helminths" will initiate the dialogue not only in the field of the history of medicine, but also in philology and botany.

\section{REFERENCES:}

1. Acharya J, Hildreth MB, Reese RN. (2014) In vitro screening of forty medicinal plant extracts from the United States Northern Great Plains for anthelmintic activity against Haemonchus contortus. Vet Parasitol. 201(1-2):75-81.

2. Adamson PB. (1988) Dracontiasis in antiquity. Med Hist. 32(2):204-209.

3. Akhlaq A, Mehmood MH, Rehman A, Ashraf Z, Syed S, Bawany SA, Gilani AH, Ilyas M, Siddiqui BS. (2016) The Prokinetic, Laxative, and Antidiarrheal Effects of Morus nigra: Possible Muscarinic, Ca (2+) Channel Blocking, and Antimuscarinic Mechanisms. Phytother Res. 30(8):1362-76.

33 Williams AR, Peña-Espinoza MA, Boas U, Simonsen HT, Enemark HL, Thamsborg SM. (2016) Anthelmintic activity of chicory (Cichorium intybus): in vitro effects on swine nematodes and relationship to sesquiterpene lactone composition. Parasitology. 143(6):770-7.

34 Yannou-Melas T. (2009) The correlation of the Arabic notes on Dioscurides' book De Materia Medica with the Greek description of the herbs and their diachronic pharmaceutical value (Doctoral Dissertation). University of Ioannina, Medical Faculty. p. 75. 
4. Ali M, Eldahab MA, Mansour HA, Nigm A. (2016) Schistosoma mansoni: Antiparasitic effects of orally administered Nigella sativa oil and/or Chroococcus turgidus extract. Acta Biol Hung. 67(3):247-60.

5. Ashrafian H. (2005) Herod the Great and his worms. J Infect. 51(1):82-3.

6. Bouras-Vallianatos P. (2014) Clinical experience in late antiquity: Alexander of Tralles and the therapy of epilepsy. Med Hist. 58(3):337-53.

7. Christopoulou-Aletra H, Papavramidou N. (2004) Methods used by the hippocratic physicians for weight reduction. World J Surg. 28(5):513-7.

8. De Castro CC, Costa PS, Laktin GT, de Carvalho PH, Geraldo RB, de Moraes J, Pinto PL, Couri MR, Pinto Pde F, Da Silva Filho AA. (2015) Cardamonin, a schistosomicidal chalcone from Piper aduncum L. (Piperaceae) that inhibits Schistosoma mansoni ATP diphosphohydrolase. Phytomedicine. 22(10):921-8.

9. Dejani NN, Souza LC, Oliveira SR, Neris DM, Rodolpho JM, Correia RO2, Rodrigues V, Sacramento LV, Faccioli LH, Afonso A, Anibal FF. (2014) Immunological and parasitological parameters in Schistosoma mansoni-infected mice treated with crude extract from the leaves of Mentha x piperita L. Immunobiology. 219(8):627-32.

10. Del Brutto OH, García HH. (2015) Taenia solium Cysticercosis -The lessons of history. J Neurol Sci. 359(1-2):392-5.

11. El-Sayad M, Abu Helw S, El-Taweel H, Aziz M. (2017) Antiparasitic Activity of Mirazid, Myrrh Total Oil and Nitazoxanide Compared to Praziquantel on Schistosoma mansoni: Scanning Electron Microscopic Study. Iran J Parasitol. 12(3):446-452.

12. Godinho LS, Aleixo de Carvalho LS, Barbosa de Castro CC, Dias MM, Pinto Pde F, Crotti AE, Pinto PL, de Moraes J, Da Silva Filho AA. (2014) Anthelmintic activity of crude extract and essential oil of Tanacetum vulgare (Asteraceae) against adult worms of Schistosoma mansoni. Sci World J. 2014:460342.

13. Golzari SE, Kazemi A, Ghaffari A, Ghabili K. (2012) A brief history of elephantiasis. Clin Infect Dis. 55(7):1024.

14. Jirsa F, Winiwarter V. (2010) Intestinal helminths in the works of Galen. Wien Klin Wochenschr. 122Suppl3:14-8.

15. Koraēs A. (1832) Atakta, ēgun pantodapōn eis tēn archaian kai tēn nean hellēniken glōssan autoschediōn sēmeiōseōn, kai tinōn allōn hypomnematōn autoschedios synagōgē: Alphabēton deuteron. Didot. Vol 4. p. 286.

16. Leatherwood C, Panush RS. (2017) Did King Herod suffer from a rheumatic disease? Clin Rheumatol. 36(4):741-744.

17. Lev E, Amar Z. (2008) Practical Materia Medica of the Medieval Eastern Mediterranean According to the Cairo Genizah. Brill. p. 375.

18. Martelli M. (2018) Translating Ancient Alchemy: Fragments of Graeco-Egyptian Alchemy in Arabic Compendia. Ambix. p. 1-17.

19. Mitchell PD. (2017) Human parasites in the Roman World: health consequences of conquering an empire. Parasitology. 144(1):48-58. 
20. Othman AA, Soliman RH. (2015) Schistosomiasis in Egypt: A never-ending story? Acta Trop. 148:179-90.

21. Panteleakos G. (2013) Physiology in the Byzantine Period 330-1453 AD (Doctoral Dissertation). National and Kapodistrian University of Athens.p. 58.

22. Petrovska BB. (2012) Historical review of medicinal plants' usage. Pharmacogn Rev. 6(11):1-5.

23. Prasad PV. (2002) General medicine in Atharvaveda with special reference to Yaksma (consumption/tuberculosis). Bull Indian Inst Hist Med Hyderabad. 32(1):1-14.

24. Ramoutsaki IA, Dimitriou H, Kalmanti M. (2002) Management of childhood diseases in the Byzantine period: I -- analgesia. Pediatr Int. 44(3):335-7.

25. Rendle-Short J. (2011) Worms in History with Special Reference to Children. Proc R Soc Med. 1957;50(12):1013-1018; Dolianiti M. Hippocrates as a pediatrician (Doctoral Dissertation). National and Kapodistian University of Athensp. 43.

26. Trompoukis C, German V, Falagas ME. (2007) From the roots of parasitology: Hippocrates' first scientific observations in helminthology. J Parasitol. 93(4):970-2.

27. Vassilyadi F, Panteliadou AK, Panteliadis C. (2013) Hallmarks in the history of enteral and parenteral nutrition: from antiquity to the 20th century. Nutr Clin Pract. 28(2):209-17.

28. Warrier PK. (1995) Filariasis (Shlipada). Bull Indian Inst Hist Med Hyderabad. 25(1-2):38-45.

29. WHO (updated September 2017), Soil transmitted helminth infections -Fact sheet,http://www.who.int/mediacentre/factsheets/fs366/en/, last retrieved 23/01/2018, 3:38 am.

30. Williams AR, Peña-Espinoza MA, Boas U, Simonsen HT, Enemark HL, Thamsborg SM. (2016) Anthelmintic activity of chicory (Cichorium intybus): in vitro effects on swine nematodes and relationship to sesquiterpene lactone composition. Parasitology. 143(6):770-7.

31. Yannou-Melas T. (2009) The correlation of the Arabic notes on Dioscurides' book De Materia Medica with the Greek description of the herbs and their diachronic pharmaceutical value (Doctoral Dissertation). University of Ioannina, Medical Faculty, p. 75.

\section{SAŽETAK}

Bolest helmintijaza poznata je još od antičkog doba, ali je i danas značajan javnozdravstveni problem. U davnim su vremenima, u potrazi za učinkovitim lijekom, mnoge biljke iskušane kao mogući terapeutik. Ovaj rad istražuje drevna vjerovanja vezana uza zarazu parazitskim crvima. Štoviše, raspravlja se o prijedlozima Aleksandra iz Trala (525. - 605.) vezanim uz liječenje ovog stanja, koji su izneseni u njegovu manje poznatom djelu Pismo o helminthima, zajedno s komentarima o upotrebi tih biljnih lijekova u suvremenoj medicini.

Ključne riječi: helminthiasis; zaraza crvima; paraziti; povijest; Aleksandar iz Trala; Bizant 